\title{
EFEKTIVITAS PEMBELAJARAN MATEMATIKA BERBASIS MULTIPLE INTEELIGENCES BERBANTUAN MEDIA BONSANGKAR TERHADAP HASIL BELAJAR SISWA PADA MATERI OPERASI HITUNG PECAHAN
}

\author{
Lutvi Anggraini'), Mohammad Edy Nurtamam²), Mujtahidin ${ }^{3)}$ \\ Program Studi PGSD FIP Universitas Trunojoyo Madura \\ E-mail: lutvianggraini93@gmail.com
}

\begin{abstract}
Abstrak
Tujuan penelitian ini yaitu untuk mengetahui efektivitas pembelajaran matematika berbasis multiple intelligences berbantuan media bonsangkar terhadap hasil belajar siswa, ditinjau dari ketuntasan hasil belajar berbasis multiple intelligences, aktivitas siswa, aktivitas guru, dan respon siswa. Penelitian ini menggunakan pendekatan kuantitatif quasi eksperimental dengan desain penelitian untreaded control group design with pretest and posttest. Sampel yang digunakan adalah seluruh siswa kelas IV SDN Kamal 2. Pengumpulan data menggunakan teknik tes, observasi, dan angket. Data yang telah terkumpul kemudian dianalisis menggunakan uji statistik.

Pembelajaran matematika berbasis multiple intelligences berbantuan media bonsangkar dinyatakan efektif karena secara klasikal $91,67 \%$ hasil belajar siswa dinyatakan tuntas, terdapat hubungan positif secara simultan antara tingkat kecenderungan kecerdasan matematis logis dan visual spasial terhadap hasil belajar siswa sebesar 0,886 dengan kategori hubungan sangat kuat, rata-rata aktivitas siswa sebesar 3,59 tergolong sangat baik, rata-rata aktivitas guru sebesar 3,88 tergolong sangat baik, dan rata-rata respon siswa $96 \%$ berkategori sangat baik.
\end{abstract}

Kata kunci: efektivitas, multiple intelligences, media bonsangkar, hasilbelajar

\section{PENDAHULUAN}

Pendidikan dasar memiliki peranan yang sangat penting dalam upaya meningkatkan kualitas sumber daya manusia dimasa yang akan datang. Salah satu komponen pendidikan tingkat sekolah dasar yang dapat meningkatkan sumber daya manusia adalah melalui bidang-bidang pembelajaran, yang salah satunya yaitu pembelajaran matematika. Menurut Wibowo, dkk (2015:1) pembelajaran matematika berfungsi untuk mengembangkan kemampuan berkomunikasi aljabar, aritmatika, geometri dan ketajaman penalaran sehingga dapat membantu siswa untuk menyelesaikan permasalahan dalam kehidupan sehari-hari. Contoh permasalahan sehari-hari siswa yang berhubungan dengan konsep matematika yaitu mengenai jual beli barang, penjumlahan harga-harga benda yang dibeli, perhitungan uang sisa pembayaran, pembagian barang, kelipatan barang, dan lain-lain. Oleh karenanya pembelajaran matematika ini penting diajarkan sejak dini guna meningkatkan sumber daya manusia.

Matematika merupakan ilmu pengetahuan yang mempelajari strukur yang abstrak dan pola hubungan yang ada di dalamnya (Subarinah, 2006:1). Hal ini menunjukkan bahwa belajar matematika pada hakekatnya adalah belajar konsep, struktur konsep, dan mencari hubungan antar konsep dan strukturnya. Sehingga untuk dapat membelajarkan konsep dan strukturnya serta mencari hubungan antara keduanya bukanlah hal yang sederhana yang dapat dilakukan oleh guru kepada siswa.

Berdasarkan hasil obervasi dan wawancara yang telah dilaksanakan pada tanggal 26 Oktober 2015 menunjukkan bahwa siswa kelas IV SDN Kamal 2 masih kesulitan dalam pemahaman terhadap operasi hitung pada suatu materi. Hal ini dapat dibuktikan dengan a) adanya 
siswa yang menanyakan kembali kepada guru ketika diberikan tugas, b) masih terdapat beberapa kesalahan dalam mengerjakan operasi hitung akibat kurangnya tingkat kecermatan siswa, c) serta ditunjukkan pula dengan hasil Ujian Tengah Semester (UTS) siswa yang kurang optimal yakni 39 siswa dari 48 siswa atau $81 \%$ dari jumlah siswa belum mencapai standar ketuntasan minimal. Menurut guru hal yang menyebabkan hasil belajar siswa kurang baik adalah lemahnya siswa dalam melakukan operasi hitung perkalian dan pembagian. Karena kelemahan siswa itulah, siswa akan kesulitan dalam memahami materi selanjutnya yaitu materi operasi hitung pecahan.

Upaya untuk mengatasi problem dalam pembelajaran matematika harus diupayakan secara terus-menerus oleh guru. Seiring dengan berkembangnya zaman, dewasa ini telah banyak teoriteori yang menjelaskan tentang bagaimana pendekatan-pendekatan yang dapat diupayakan guru untuk meningkatkan pembelajaran. Salah satu teori mutakhir saat ini adalah teori Multiple Intelligences yang disampaikan oleh Howard Gardner. Howard Gardner (dalam Chatib, 2012:79) menyatakan bahwa otak manusia setidaknya menyimpan sembilan jenis kecerdasan yang disepakati, sedangkan yang selebihnya masih misteri. Kesembilan kecerdasan tersebut yaitu kecerdasan linguistik, matematis logis, visual spasial, kinestetik, musikal, interpersonal, intrapersonal, naturalis, dan eksistensial. Teori ini mengungkapkan bahwa jika pembelajaran dilaksanakan sesuai dengan kecerdasan ganda yang dimiliki oleh siswa maka diasumsikan hasil belajar siswa akan lebih optimal. Oleh karenanya pendekatan multiple intelligences dapat dijadikan sebagai salah satu alternatif pembelajaran matematika untuk mengatasi permasalahan pembelajaran yakni memudahkan siswa untuk dapat memahami materi operasi hitung pecahan.

Materi pembelajaran matematika pada operasi hitung pecahan memiliki beberapa permasalahan. Permasalahan-permasalahan yang sering dihadapi siswa diantaranya a) siswa kesulitan dalam memahami bentuk pecahan, b) menjumlahkan atau mengurangkan pembilang dengan pembilang atau penyebut dengan penyebut, c) salah dalam menyamakan penyebut, d) penyebut sudah disamakan tetapi penyebut belum disesuaikan, e) kurang teliti dalam melakukan operasi hitung. Adanya permasalahan-permasalahan tersebut disebabkan karena siswa belum memahami benar makna pecahan serta pengoperasian pecahan masih bersifat abstrak. Untuk mengatasi hal tersebut maka gambar dan bentuk pecahan yang konkret serta adanya eksperimeneksperimen mini dapat digunakan untuk membantu siswa dalam memahami bentuk pecahan serta pengoperasian pecahan. Oleh karenanya solusi yang sesuai untuk dapat mengatasi hal tersebut yaitu dengan melaksanakan pembelajaran yang menstimulasi kecerdasan visual spasial dan matematis logis.

Kecerdasan visual spasial adalah kecerdasan yang lebih menonjolkan pada gambar dan visualisasi. Sehingga salah satu strategi pembelajaran yang sesuai dengan materi operasi hitung pecahan guna menstimulasi kecerdasan visual spasial siswa adalah dengan menggunakan potongan kertas warna-warni (Mujtahidin, 2015:32). Kecerdasan matematis logis kecerdasan tentang angka-angka dan penalaran. Salah satu strategi pembelajaran yang menstimulasi kecerdasan matematis logisadalah dengan menggunakan metode eksperimen. Salah satu bentuk media pembelajaran yang dikembangkan untuk dapat menstimulasi kecerdasan visual spasial dan matematis logis siswa yaitu media pembembelajaran bonsangkar (media kartu berwarna yang dapat dibongkar pasang).

Penelitian senada yang mendukung penelitian ini diantaranya penelitian yang dilakukan oleh Mathri (2012) dengan judul "Penerapan Multiple Intelligences dalam Metode Diskusi untuk Meningkatkan Hasil Belajar Matematika Siswa Kelas V SDN 025 Desa Sibiruang Kec.XIII Koto Kampar" yang menyimpulkan bahwa penerapan multiple intelligence dalam metode diskusi dapat meningkatkan hasil belajar siswa. Saputra dkk (2015) dengan judul "Pengaruh Strategi Pembelajaran Berbasis Multiple Intelligences terhadap Hasil Belajar" menyimpulkan bahwa terdapat pengaruh yang signifikan pada penerapan strategi pembelajaran berbasis multiple intelligences terhadap hasil belajar kognitif siswa. Solikhah (2015) dengan judul "Pengaruh Pembelajaran Berbasis Multiple Intelligences terhadap Hasil Belajar Matematika Siswa Kelas III SDN Brayu Blandong Mojokerto" menyimpulkan bahwa terdapat pengaruh antara pembelajaran berbasis Multiple Intelligences terhadap hasil belajar matematika siswa materi keliling dan luas bangun datar (persegi dan persegi panjang) kelas III SDN Brayublandong. 
Berdasarkan uraian penelitian-penelitian di atas, maka dapat diasumsikan bahwa pembelajaran matematika berbasis multiple intelligences berbantuan media bonsangkar efektif dalam meningkatkan hasil belajar siswa pada materi operasi hitung pecahan. Oleh karena itu tujuan penelitian ini yaitu: (1) mendeskripsikan perangkat pembelajaran matematika berbasis multiple intelligences berbantuan media bonsangkarpada materi operasi hitung pecahan, (2) untuk mengetahui efektivitas pembelajaran matematika berbasis multiple intelligences berbantuan media bonsangkarterhadap hasil belajar siswa (kognitif) pada materi operasi hitung pecahan.

\section{METODE}

Rancangan penelitian yang digunakan pada penelitian ini yaitu quasi eksperimental. Desain penelitian yang digunakan dalam rancangan penelitian quasi eksperimental adalah untreaded control group design with pretest and posttest. Dengan desain tersebut maka sampel dibagi kedalam dua kelas, kelas eksperimen dan kelas kontrol. Kelas yang diberikan perlakuan hanya kelas eksperimen.

Populasi dalam penelitian ini adalah seluruh siswa kelas IVSD Negeri Kamal 2 Semester II Tahun Ajaran 2015/2016, yakni berjumlah 48 siswa.Adapun teknik pengambilan sampel yang digunakan yaitu teknik sampling purposive. Sehingga sampel yang digunakan adalah siswa yang memiliki minimal 50\% kecenderungan kecerdasan matematis logis dan/atau visual spasial.

Teknik pengambilan data yang digunakan yaitu tes, observasi, dan angket. Sehingga instrumen yang digunakan yaitu tes hasil belajar, lembar observasi aktivitas siswa, lembar observasi aktivitas guru, dan angket respon siswa. Sebelum digunakan, instrumen terlebih dahulu divalidasi oleh praktisi dan ahli dengan minimal dinyatakan cukup layak.

Uji statistik yang digunakan untuk menganalisis data pretest dan posttest siswa yaitu uji dua sampel independent, uji gain ternormalisasi, uji korelasi berganda, uji koefisien determinasi. Analisis data aktvitas siswa menggunakan perhitungan rata-rata aktivitas siswa. Analisis data aktvitas guru menggunakan perhitungan rata-rata keterlaksanaan pembelajaran. Analisis data respon siswa menggunakan perhitungan jumlah siswa yang merespon positif dibandingkan dengan jumlah seluruh siswa dikalikan $100 \%$.

\section{HASIL DAN PEMBAHASAN}

\section{VALIDITAS PERANGKAT PEMBELAJARAN DAN INSTRUMEN}

Perangkat pembelajaran yang digunakan dalam penelitian ini yaitu silabus, RPP, dan media bonsangkar. Berikut hasil validitas perangkat pembelajaran yang telah divalidasi oleh para ahli yang sesuai dengan kompetensinya. Rata-rata validitas silabus $85,25 \%$ dengan kualifikasi sangat layak, rata-rata validitas RPP 87,5\% dengan kualifikasi sangat layak, rata-rata validitas media bonsangkar $96,25 \%$ dengan kualifikasi sangat layak.

Instrumen yang digunakan dalam penelitian ini yaitu angket kecerdasan multiple intelligences (MI), lembar observasi aktivitas siswa, lembar observasi aktivitas guru, angket respon siswa, dan tes hasil belajar berbasis MI. Berikut hasil validitas instrumen yang telah divalidasi oleh para ahli yang sesuai dengan kompetensinya. Angket kecerdasan MI memiliki validitas kelayakan $80 \%$ dengan kualifikasi sangat layak. Lembar observasi aktivitas siswa memiliki rata-rata validitas kelayakan 100\% dengan kualifikasi sangat layak. Lembar observasi aktivitas guru memiliki rata-rata validitas kelayakan 93\% dengan kualifikasi sangat layak. Angket respon siswa memiliki rata-rata validitas kelayakan $91 \%$ dengan kualifikasi sangat layak.

\section{PERANGKAT PEMBELAJARAN}

Silabus pembelajaran yang digunakan dalam penelitian memuat sekolah, kelas, semester, mata pelajaran, standar kompetensi, kompetensi dasar, indikator, materi pokok, teknik penilaian, bentuk instrumen, alokasi waktu, media dan sumber belajar lainnya. Seluruh isi dari silabus saling berkaitan antara satu dan yang lainnya. Dengan kegiatan pembelajaran yang digunakan 
menggunakan tahapan pembelajaran ICARE (Introduction, Connection, Application, Reflection, Exploration).

Rencana Pelaksanaan Pembelajaran (RPP) disusun berdasarkan silabus yang telah disusun sebelumnya. Adapaun tahapan-tahapan pembelajaran yang digunakan dalam kegiatan pembelajaran operasi hitung pecahan berbasis pendekatan multiple intelligences khususnya visual spasial dan matematis logis yaitu menggunakan tahapan pembelajaran ICARE. Tahapan introduction adalah tahapan awal pengenalan pada siswa Tahapan connection adalah tahapan mengaitkan pengetahuan awal siswa dengan materi pembelajaran. Tahapan application adalah tahapan penerapan bagi siswa untuk menerapkan materi yang sedang dipelajari. Tahapan reflection adalah tahapan siswa merefleksikan kembali mengenai apa saja yang telah dipelajari dan menemukan kesimpulan dari pembelajaran yang telah dilaksanakan. Tahapan terakhir yaitu exploration, pada tahap ini siswa diharapkan untuk dapat mengembangkan pengetahuannya yaitu salah satunya melalui tugas-tugas yang diberikan oleh guru.

Media pembelajaran yang digunakan dalam penelitian ini memuat beberapa hal. Pertama pentunjuk penggunaan media pembelajaran bonsangkar. Kedua pedoman melakukan operasi hitung pecahan berpenyebut sama. Ketiga pedoman melakukan operasi hitung pecahan berbeda penyebut. Keempat praktik penggunaan media pembelajaran bonsangkar.

\section{HASIL UJI COBA INSTRUMEN TES HASIL BELAJAR BERBASIS MI}

Instrumen tes hasil belajar berbasis MI yang telah dinyatakan valid dan layak digunakan, kemudian diujicobakan kepada sekolah yang telah menerima materi pecahan. Data hasil uji coba kemudian dianalisis tingkat validitas, reliabilitas, daya pembeda, dan kesukaran soal. Analisis validitas soal dengan menggunakan rumus korelasi product moment menunjukkan 22 dari 25 butir soal dinyatakan valid yaitu $r_{\text {hitung }}>r_{\text {tabel. }}$. Analisis reliabilitas soal menggunakan rumus spearmam brown menggunakan metode belahan awal dan akhir, menunjukkan bahwa instrumen yang digunakan reliabel dengan $r_{11}=0,7719>r_{\text {tabel }}=0,320$. Analisis daya pembeda soal (valid) menunjukkan bahwa 4 butir soal memiliki daya pembeda berkategori cukup baik, 11 butir soal memiliki daya pembeda berkategori baik dan 7 lainnya memiliki daya pembeda dengan kategori sangat baik, dengan rata-rata daya pembeda berkategori baik. Analisis tingkat kesukaran soal (valid) menunjukkan 4 butir soal dikategorikan mudah, 13 butir soal berkategori sedang, dan 5 butir soal berkategori sukar. Berdasarkan penjelasan tersebut maka untuk memenuhi proporsi tingkat kesukaran soal jumlah butir soal yang diguanakan yaitu 20 butir soal dengan 4 buitr soal mudah, 12 butir soal sedang, dan 4 butir soal lainnya sukar.

\section{ANALISIS DATA ANGKET KECERDASAN MI}

Data angket kecerdasan MI menunjukkan pada kelas eksperimen 22 siswanya memiliki kecenderungan kecerdasan matematis logis dan visual spasial, 1 siswa lainnya memiliki kecenderungan kecerdasan matematis logis, dan 1 siswa lainnya memiliki kecenderungan kecerdasan visual spasial. Sedangkan pada kelas kontrol 22 siswa memiliki kecenderungan kecerdasan matematis logis dan visual spasial, sedangkan 2 siswa lainnya memiliki kecenderungan kecerdasan visual spasial. Oleh karenanya dapat disimpulkan bahwa seluruh populasi memiliki kecenderungan kecerdasan visual spasial dan/atau matematis logis sehingga seluruh populasi dapat digunakan sebagai sampel penelitian.

\section{ANALISIS DATA TES HASIL BELAJAR BERBASIS MI}

Tes hasil belajar berbasis MI yang digunakan merupakan tes hasil belajar berbasis multiple intelligences berjumlah 20 soal yang telah diujicobakan sebelumnya, dan telah memenuhi tingkat validitas, reliabilitas, daya pembeda, serta tingkat kesukaran soal yang proporsional. Berikut hasil pretest dan posttest kelas eksperimen dan kelas kontrol.

\section{Tabel 1}

Rata-rata Hasil Pretest dan Posttest Kelas Eksperimen dan Kontrol

\begin{tabular}{|c|c|c|}
\hline Kelas & Rata-rata Pretest & Rata-rata Posttest \\
\hline Eksperimen & 42,50 & 85,21 \\
\hline
\end{tabular}




\begin{tabular}{|c|c|c|}
\hline Kontrol & 41,25 & 73,75 \\
\hline
\end{tabular}

Sebelum melakukan analisis tes hasil belajar berbasis MI, maka terlebih dahulu melakukan uji prasyarat yaitu uji homogenitas dan uji normalitas.Hasil uji homogenitas data pretest dari kedua kelas yaitu bahwa $F_{\text {hitung }}=1,523$ dan $F_{\text {tabel }}=2,014$, sehingga dapat disimpulkan bahwa tidak ada perbedaan pretest antara kelas ekperimen dan kelas kontrolkelas eksperimen dan kelas kontrol (homogen). Uji normalitas ini digunakan untuk mengetahui apakah data terdistribusi secara normal atau tidak.

Tabel 2

Tabel Uji Normalitas

\begin{tabular}{|c|c|c|c|c|}
\hline Test & Kelas & Dhitung & $\mathbf{D}_{\text {tabel }}$ & Keputusan \\
\hline \multirow{2}{*}{ Pretest } & Eksperimen & 0,162 & \multirow{4}{*}{0,275} & $\begin{array}{c}\text { Ho diterima } \\
\text { (data berdisribusi normal) }\end{array}$ \\
\hline & Kontrol & 0,173 & & $\begin{array}{c}\text { Ho diterima } \\
\text { (data berdisribusi normal) }\end{array}$ \\
\hline \multirow{2}{*}{ Posttest } & Eksperimen & 0,175 & & $\begin{array}{c}\text { Ho diterima } \\
\text { (data berdisribusi normal) }\end{array}$ \\
\hline & Kontrol & 0,172 & & $\begin{array}{c}\text { Ho diterima } \\
\text { (data berdisribusi normal) }\end{array}$ \\
\hline
\end{tabular}

Berdasarkan tabel di atas dapat disimpulkan bahwa semua data pretest dan posttest kelas eksperimen maupun kelas kontrol terdistribusi secara normal.

Setelah kedua kelas dinyatakan homogen dan semua data terdistribusi secara normal maka dapat dilakukan analisis data tes hasil belajar berbasis MI dengan menggunakan uji-t dua sampel independent dan uji gain ternormalisasi. Berdasarkan perhitungan uj-t dua sampel independent diketahui $t_{\text {hitung }}=3,132>\mathrm{t}_{\text {tabel }}=2,013$, maka hasil belajar (posttest) antara kelas eksperimen dan kelas kontrol terdapat perbedaan, terbukti dengan rata-rata posttest kelas eksperimen lebih unggul. Untuk mengetahui peningkatan hasil belajar kelas eksperimen, maka digunakan uji gain ternormalisasi. rata-rata uji-Gain pada kelas eksperimen yang diperoleh yaitu $(\mathrm{g})=0,779$, dengan kriteria peningkatan hasil belajar tinggi.

\section{ANALISIS DATA EFEKTIVITAS PEMBELAJARAN}

\section{KETUNTASAN HASIL BELAJAR BERBASIS MI}

Pada mata pelajaran matematika untuk siswa kelas IV, kriteria ketuntasan minimal yang digunakan adalah 68. Oleh karenanya siswa dapat dinyatakan tuntas apabila minimal hasil belajarnya adalah lebih besar sama dengan $68(\geq 68)$. Berdasarkan test hasil belajar siswa (posttest) diketahui bahwa 22 siswa dari 24 siswa dinyatakan tuntas. Hal ini menunjukkan bahwa ketuntasan hasil belajar siswa secara klasikal yaitu mencapai $91,67 \%$.

\section{HUBUNGAN PEMBELAJARAN MATEMATIKA BERBASIS MI BERBANTUAN MEDIA BONSANGKAR DENGAN HASIL BELAJAR}

Pembelajaran matematika berbasis multiple itelligences berbantuan media bonsangkar yang digunakan pada penelitian ini merupakan suatu pendekatan pembelajaran multiple intelligences dengan menstimulasi kecerdasan matematis logis dan visual spasial. Untuk mengetahui hubungan stimulasi kecerdasan matematis logis dan visual spasial yang digunakan menggunakan uji korelasi berganda. Uji korelasi berganda digunakan untuk mengetahui derajat atau kekuatan hubungan antara tiga variabel atau lebih, serta untuk mengetahui kontribusi yang diberikan secara simultan oleh variabel $\mathrm{X}_{1}$ dan $\mathrm{X}_{2}$ terhadap nilai variabel $\mathrm{Y}$, yang disajikan dalam gambar sebagai berikut.

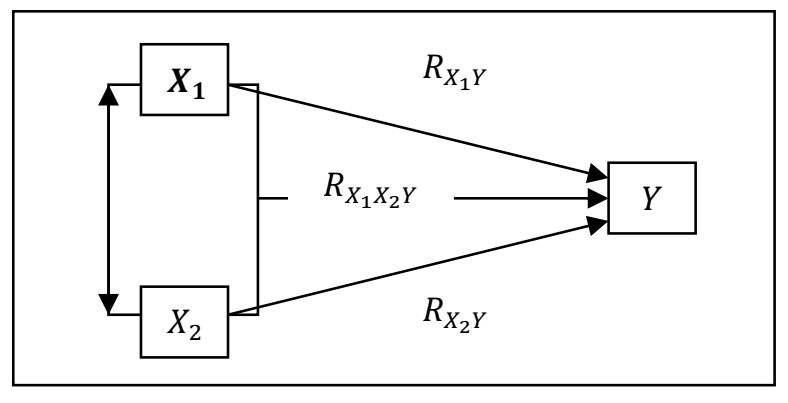


$\underline{\text { Variabel bebas }}$

\section{Gambar 1 Desain Korelasi Berganda}

$\mathrm{X}_{1}=$ Tingkat kecenderungan kecerdasan matematis logis

$\mathrm{X}_{2}=$ Tingkat kecenderungan kecerdasan visual spasial

Variabel terikat

$\mathrm{Y}=$ Hasil belajar setelah mendapatakan perlakuan

Berikut hasil korelasi melalui SPSS versi 16.

\begin{tabular}{|ll|r|r|r|}
\hline \multicolumn{1}{|c|}{ Correlations } \\
Tingkat Kecerdasan & $\begin{array}{c}\text { Tingkat Kecerdasan } \\
\text { Matematis Logis }\end{array}$ & $\begin{array}{c}\text { Tingkat Kecerdasan } \\
\text { Visual Spasial }\end{array}$ & Hasil Belajar \\
\hline Matematis Logis & Pearson Correlation & 1 & $.477^{*}$ & $.801^{* *}$ \\
& Sig. (2-tailed) & .018 & .000 \\
& $\mathrm{~N}$ & 24 & 24 & 24 \\
\hline Tingkat Kecerdasan Visual & Pearson Correlation & $.477^{*}$ & 1 & $.716^{* *}$ \\
Spasial & Sig. (2-tailed) & .018 & .000 \\
& $\mathrm{~N}$ & 24 & 24 & 24 \\
\hline Hasil Belajar & Pearson Correlation & $.801^{* *}$ & $.716^{* *}$ & 1 \\
& Sig. (2-tailed) & .000 & .000 & 24 \\
& $\mathrm{~N}$ & 24 & 24 \\
\hline
\end{tabular}

*. Correlation is significant at the 0.05 level (2-tailed).

**. Correlation is significant at the 0.01 level (2-tailed).

Dari tabel correlations menunjukkan bahwa hubungan (korelasi) antara tingkat kecerdasan matematis logis $\left(\mathrm{X}_{1}\right)$ dengan hasil belajar siswa $(\mathrm{Y})$ adalah positif 0,801 dengan kategori hubungan sangat kuat. Sedangkan hubungan (korelasi) antara tingkat kecerdasan visual spasial $\left(\mathrm{X}_{2}\right)$ dengan hasil belajar siswa (Y)adalah positif 0,716 dengan kategori hubungan kuat.

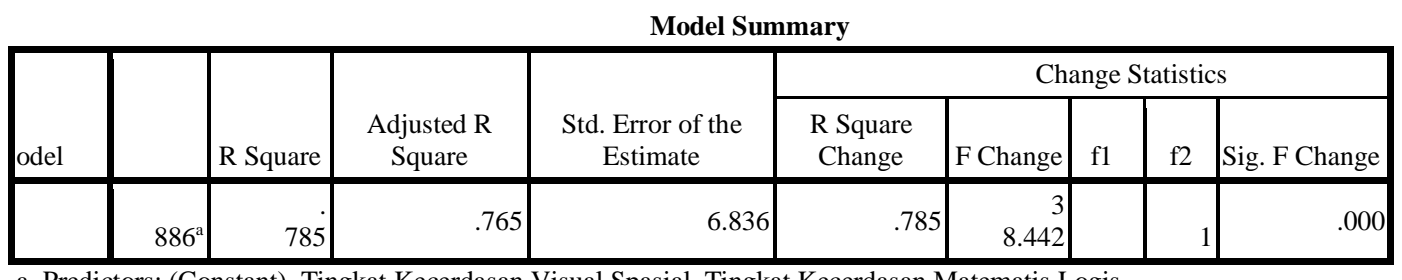

a. Predictors: (Constant), Tingkat Kecerdasan Visual Spasial, Tingkat Kecerdasan Matematis Logis

Berdasarkan tabel model summary diperoleh besarnya hubungan antara variabel tingkat kecerdasan matematis logis dan visual spasial secara silmultan terhadap hasil belajar adalah 0,886 , dengan kategori hubungan sangat kuat. Sehingga koefisien determinasinya dapat diketahui sebesar $\mathrm{D}=\mathrm{r}_{\mathrm{xy}}{ }^{2} \times 100 \%=(0,886)^{2} \times 100 \%=78,5 \%$. Berdasarkan perhitungan tersebut maka dapat diketahui bahwa kontribusi secara simultan variabel $\mathrm{X}_{1}$ dan $\mathrm{X}_{2}$ terhadap hasil belajar yaitu 78,5\% sedangkan sisanya $21,5 \%$ dipengaruhi oleh variabel lain.

\section{AKTIVITAS SISWA}

Data aktivitas siswa ini, di dapatkan dari penilaian yang dilakukan oleh tiga orang observer selama proses pembelajaran berbasis multiple intelligences berbantuan media bonsangkar berlangsung yaitu selama dua kali pertemuan.Pada pertemuan pertama aktivitas belajar siswa 
memiliki rata-rata 3,46 yang berkategori baik. Pada pertemuan kedua aktivitas belajar siswa memiliki rata-rata 3,73 yang berkategori sangat baik. Hal ini menunjukkan adanya peningkatan aktivitas belajar siswa yakni pada pertemuan pertama rata-rata aktivitas belajar siswa sebesar 3,45 , meningkat menjadi 3,73 pada pertemuan kedua.

\begin{abstract}
AKTIVITAS GURU
Data aktivitas guru ini, di dapatkan dari penilaian yang dilakukan oleh praktisi pendidikan selama proses pembelajaran berbasis multiple intelligences berbantuan media bonsangkar berlangsung yaitu selama dua kali pertemuan.Pada pertemuan pertama sebesar 3,83 dengan kategori sangat baik, dan pada pertemuan kedua sebesar 3,93 dengan kategori sangat baik. Oleh karenanya secara umum pembelajaran dari pertemuan pertama dan kedua terjadi peningkatan aktivitas guru, dengan kategori aktivitas guru sangat baik.
\end{abstract}

\title{
RESPON SISWA
}

Respon siswa merupakan tanggapan siswa terhadap pembelajaran yang telah dilaksanakan. Data mengenai respon siswa diperoleh melalui hasil angket respon siswa yang diberikan setelah pembelajaran.Hasil respon siswa secara keseluruhan $96 \%$ respon siswa terhadap pembelajaran matematika berbasis multiple intelligences berbantuan media bonsangkar adalah positif.

\section{KESIMPULAN DAN SARAN}

\section{SIMPULAN}

Berdasarkan pembahasan yang telah diuraikan maka dapat diketahui bahwa perangkat pembelajaran yang digunakan telah divalidasi oleh para ahli yang sesuai dengan kompetensinya. Rata-rata validitas silabus $85,25 \%$ dengan kualifikasi sangat layak, rata-rata validitas RPP 87,5\% dengan kualifikasi sangat layak, rata-rata validitas media bonsangkar 96,25\% dengan kualifikasi sangat layak. Dapat diketahui pula efektivitas berdasarkan kelima indikator efektivitas pembelajaran: a) secara klasikal 91,67\% siswa dinyatakan memiliki ketuntasan hasil belajar, b) hubungan pembelajaran matematika berbasis multiple intelligences berbantuan media bonsangkar secara simultan antara tingkat kecenderungan kecerdasan matematis logis dan visual spasial terhadap hasil belajar siswa sebesar 0,886 dengan berkategori sangat kuat, c) rata-rata aktivitas belajar siswa yaitu 3,59 tergolong berkategori sangat baik, d) rata-rata aktivitas guru yaitu 3,88 tergolong berkategori sangat baik, e) rata-rata respon siswa yaitu 96\% tergolong berkategori sangat baik. Sehingga pembelajaran matematika berbasis multiple intelligences berbantuan media bonsangkar efektif dalam meningkatkan hasil belajar siswa pada materi operasi hitung pecahan.

Berdasarkan uraian di atas, maka dapat diketahui bahwa hasil belajar siswa, aktivitas siswa dan guru, serta respon siswa terhadap pembelajaran dinyatakan sangat baik. Hal ini disebabkan oleh pembelajaran yang dilaksanakan sesuai dengan jenis kecerdasan siswa sehingga siswa dapat belajar dengan senang serta hasilnyapun optimal. Sehingga dapat disimpulkan bahwa terdapat kesesuaian antara hasil penelitian dengan teori pendekatan multiple intelligences berbantuan media bonsangkar. Oleh karena itu penelitian dengan judul "Efektivitas Pembelajaran Matematika Berbantuan Media Bonsangkar terhadap Hasil Belajar Siswa pada Materi Operasi Hitung Pecahan" dinyatakan berhasil. 


\section{SARAN}

Berdasarkan penelitian yang telah dilaksanakan, maka peneliti menyampaikan beberapa saran, antara lain a) Sebelum melaksanakan pembelajaran hendaknya guru memperhatikan jenisjenis gaya belajar siswanya, agar pembelajaran yang akan disampaikan dapat diterima dengan baik oleh siswa, b) pembelajaran selanjutnya diharapkan mengembangkan penelitian lanjutan dengan mengembangkan jenis-jenis kecerdasan lainnya, seperti kicerdasan linguistik; kinestetik; natural; musikal; interpersonal; intrapersonal; dan eksistensial, c) untuk peneliti selanjutnya, diharapkan mengembangkan penelitian lanjutan yaitu dengan mengembangkan media bonsangkar.

\section{DAFTAR RUJUKAN}

Chatib, M. 2012.Sekolahnya Manusia (Sekolah Berbasis Multiple Intellegences di Indonesia). Bandung: Kaifa.

Mathri, H. 2012. Penerapan Multiple Intelligences dalam Metode Diskusi untuk Meningkatkan Hasil Belajar Matematika Siswa Kelas V SDN 025 Desa Sibiruang Kec.XIII Koto Kampar. Skripsi Universitas Islam Negeri Sultan Syarif Kasim Riau

Mujtahidin. 2015. Teori Pengembangan Pembelajaran Berbasis Kecerdasan Majemuk (Multiple Intellegences). Bangkalan. Prodi PGSD FKIP UTM.

Saputra, dkk.2015. Pengaruh Strategi Pembelajaran Berbasis Multiple Intelligences terhadap Hasil Belajar. Jurnal Universitas Lampung

Solikhah, M. 2015.Pengaruh Pembelajaran Berbasis Multiple Intelligences terhadap Hasil Belajar Matematika Siswa Kelas III SDN Banyublandong Mojokerto. Skripsi Universitas Trunojoyo Madura.

Subarinah, S. 2006. Inovasi Pembelajaran Matematika SD. Mataram : Tidak Diterbitkan.

Wibowo, dkk. 2015. Peningkatan Aktivitas dan hasil Belajar Melalui Penerapan Pendekatan Realistic Mathematics Education. Jurnal Universitas Lampung 